Dereń Aldona-Małgorzata

PhD, Faculty of Computers Science and Management Wroclaw University of Science and Technology

(Wroclaw, Poland)

Skonieczny Jan

PhD Eng., Faculty of Computers Science and Management Wroclaw University of Science and Technology

(Wroclaw, Poland)

\title{
MARKETING INTELLECTUAL PROPERTY
}

Marketing is variously defined. However, it is most often perceived as a process described in the Marketing-mix 4P, Marketing-mix 5p and Marketing-mix 7P and created values for consumers. The new marketing-mix concept developed by the authors (Product, Patent and other Intellectual Property Rights; Price; Promotion; People; Process; Physical evidence) has important practical implications for innovative enterprises, especially those that base their market activity on new information technologies. The model thus developed is an integral part of the rail model developed by the authors, which combines marketing strategies (market penetration, product development, market development, diversification) with strategies for protection of intellectual property resources (patent, sale, license, franchise).

Keywords: marketing, new marketing-mix concept, intellectual property, patent.

\section{DOI: 10.15276/mdt.2.2.2018.2}

Statement of the problem in general form and it's connection with important scientific or practical tasks. In the historical perspective, three basic perceptions of marketing have developed: marketing as a management concept (market-orientation, focus on customer needs, focus on problem-solving, market differentiation); marketing as a form of organization (functional form of marketing, product-orientation, mixed forms); marketing as a management method (identification of the objective, planning, implementation, control) ${ }^{3}$. These concepts are constantly evolving, with the causative force being the progressing development of the civilization, modernization of technologies and globalization processes occurring in the contemporary world. The scope of these changes includes innovations and breakthrough technologies; new business models; corporate social responsibility; rivalry for standards of production and customer service; new markets of «winner takes all» type and global strategies ${ }^{4}$; Internet of Things; sharing economy; zero marginal cost society ${ }^{5}$; entrepreneurial states ${ }^{6}$. All these new solutions and ideas characterize the contemporary economy, referred to as the creative economy. The basis for the development of this economy

3 Weis H. Ch., Marketing, Friedrich Kiehl Verlag, Ludwigshafen (Rhein) 1977, p. 19; Hofner K., Probleme bei den Verwirklichung des Marketingkonzept im Investitionsgüterbereich, «Rationalisierung» 1977, no. 10.

4 Grant R. M., Contemporary strategy analysis, Wolters Kluwer business Publishing House, Warsaw 2011, p. 32.

5 Rifkin J., The Zero Marginal Cost Society, Studio Emka Publishing House, 2014.

6 Mazzucato M., The Entrepreneurial State, Wydawnictwo Ekonomiczne Heterodox Poznań, 2016. 
are: knowledge, experience, creative skills, and intellectual resources ${ }^{7}$. In the opinion of the authors, this new model of the economy assigns to the marketing a previously unknown role and area of activity. This means introduction adjustments to the 4P, 5P and 7P marketing-mix concepts, commonly known and accepted by theoreticians and practitioners, a new element referred to by us as a patent of a different intellectual property. The concept proposed by us consists of 8P (Product, Patent and other Intellectual Property Right, Price, Place, Promotion, People, Process, Physical evidence). A leading element in this concept is the patent and other protection rights pertaining to intellectual property objects. They set forth the dynamics of placement of innovative product on the market. The authors define this new type of marketing that has been shaping in the 21 st century as the marketing of intellectual assets.

Formulation of the purpose of the article (statement of the problem). The aim of the article is to analyze existing and implemented marketing concepts of business management in terms of taking intellectual resources covered by legal protection into them. The consequence of such an approach is the proposition formulated by the authors to supplement existing concepts with new components that refer directly to the specificity of intellectual resources that are subject to market exchange.

Analysis of the latest research and publications, which initiated the solution of this problem and on which the author relies. Marketing can be described in many ways. It is most often referred to as a way of thinking and acting, based on the belief that satisfying the needs of customers is conducive to achieving the goals of the enterprise ${ }^{8}$. In practice, there are three approaches to understanding marketing. In the first, basic meaning, marketing is based on advertising, promotion and active sales. The second meaning of marketing is treating it as a set of market analysis instruments, such as sales forecasting methods, simulation models and market research, used to develop a forward-looking and more scientific approach to the analysis of needs and demand. The last one - the third meaning of marketing, brings marketing to the role of the architect of the consumer society. More precisely, marketing is in this approach a market system that allows sellers to use buyers.

According to H. I. Ansoff, the 1930s saw the development of mass marketing as a consequence of constraints in the sale of mass-produced goods ${ }^{9}$. The priority of this marketing was promotion, advertising, sale and other forms of influencing the consumer, inducing him to purchase offered goods. In practice, this meant the creation of specialized organizational units in production companies, the so-called marketing departments, whose task was to examine the market and the behavior of future buyers of mass goods.

The type of marketing described above became widespread in Europe in the 1950s and was referred to as the marketing services. In subsequent years, it evolved towards other kinds of marketing, i.e. industrial marketing - the 1960s; non-profit organization marketing - the 1970s; services marketing - the 1980s; partnership marketing - the 1990s ${ }^{10}$.

The concept of partnership marketing stressed the need to create, maintain and enrich relations with the customer. In practice, this meant actions aiming at maintenance of longterm relations with customers, with other external markets, including supplier markets, potential employees, the intermediary market, and the market of influential institutions. Partnership marketing focused on integrating three elements: quality, customer service and marketing activities ${ }^{11}$.

7 Dereń A. Skonieczny J., Organizational management. Process approach, Difin Publishing House 2016.

8 Silk, A., What is marketing?, Dom Wydawniczy Rebis, Poznań 2008, p. 15.

9 Ansoff H. I., Strategic Management, Państwowe Wydawnictwo Ekonomiczne, Warsaw 1985, p. 47, 49.

10 Payne A., The Essence of Services Marketing, Polskie Wydawnictwo Ekonomiczne, Warsaw 1997, p. 50.

11 Fonfara K., Partnership Marketing, Polskie Wydawnictwo Ekonomiczne, Warsaw 1999, p. 69. 
In the last decade of the 20th century, new types of marketing emerged, the establishment of which involves development of new technologies, especially the Internet global network and the creation of the online market. The beginning of marketing in the web was the development of the Internet and the introduction of advanced communication channels thereto. They allowed for implementation of banners and mailing. Marketing in the web is based on relations that enable creation and strengthening of bonds between the brand and the recipient. This type of marketing is referred to as interactive marketing (marketing online $^{12}$, guerrilla marketing ${ }^{13}$, e-marketing $\left.{ }^{14}\right)$, which changes pursuant to the needs of recipients, who cease to be satisfied with a one-way, closed communication. Recipients appreciate true, active contact - exchange of comments on Facebook in place of another mailing, interesting forms of specialist posts instead of simple endorsing of the product, as well as dynamism consisting in the fact that the brand exists in many places, it is active everywhere, and it (along with interesting facts about it) can be reached from all devices. In network marketing, the role of the recipient is increased - he is not a passive consumer of advertising information, but a true, real person who, through communication, has the right to express his opinions and needs.

Another type of marketing that has been recently developed is the cause related marketing $(\mathrm{CRM})^{15}$ and the social media marketing. Cause related marketing requires the company to assess its chain of deliveries and ensure that the materials it receives are obtained in an ethical way. Companies may acquire a number of moral and financial benefits by taking up the initiative and applying the principles of responsible marketing and CSR:

- growing impact of high social expectations of the company involved in the globalization process;

- the company becomes more competitive and resistant to deterioration of the market situation;

- the company becomes more attractive for customers, investors, employees, gains their trust;

- CSR may facilitate financial and administrative organization and help build goodwill.

On the other hand, social media marketing is a group of marketing activities aimed at generation of traffic on the website using social media, namely popular websites such as Facebook, Google, Twitter, Linkedin, YouTube, Goldenline, Yelp, Snapchat. Some people also include in this group actions in the blogosphere, however, the latter are more associated with the word-of-mouth marketing or sponsored posts. Marketing in the social media is used by an increasing amount of companies in creating the long-term marketing strategy. It is a popular solution, since creating and running an account is usually free, and thus companies can reach many recipients with a diverse information offer concerning products and services ${ }^{16}$.

12 Levinson J. C., Rubin Ch., Guerilla Marketing on-line, Polskie Wydawnictwo Ekonomiczne, Warsaw 1998; Conrady R., Jaspersen T., Pepels W., (Hrsg.), Online Marketing Instrumente, Luchterhand Verlag, 2002.

13 Levinson J. C., Guerilla Marketing , Polskie Wydawnictwo Ekonomiczne, Warsaw 1998.

14 Królewski J., Sala P., E-marketing. Contemporary trends. Starter pack, Państwowe Wydawnictwo Naukowe PWN, Warsaw 2016.

15 «Shared responsibility. The role of marketing», (Ed.) N. Ćwik, http://odpowiedzialnybiznes.pl/wpcontent/uploads/2012/04/Wsp\%C3\%B3lna-odpowiedzialno\%C5\%9B\%C4\%87. -Rola-marketingu-13.pdf (retrieved on: 29.03.2018).

16 Evans, L., Social Media Marketing. Discover the Potential of Facebook, Twitter and other Social Networking sites, Helion, 2011. 
Statement of the main material of the research with full justification of the scientific results obtained. The literature presents various divisions of a company's resources. According to the classic approach, resources are divided into capital and work. Capital is defined as any physical property of the company, while work is defined as employees with their experience, knowledge, and skills. This approach, owing to its universality, has not become outdated. ${ }^{17}$

M.J. Dollinger distinguishes six types of resources: physical, reputational, organizational, financial, intellectual \& human, and technological resources - PROFIT ${ }^{18}$. Intellectual and human resources include the following: knowledge in the field of management, trainings, experience, challenging, observing, creativity, vision, the individual intelligence of employees, and their social competences. The authors fully share the idea that intellectual resources have a strategic importance for the development of a company and have a critical importance for the creation and maintenance of competitive advantages.

Assuming as the starting point the broadly understood notion of intangible resources, the authors propose the following classifications of intellectual resources: organic (primary) intellectual resources, and acquired (secondary) intellectual resources (see Table1) ${ }^{19}$.

Table 1 - Organic and acquired intellectual resources in the company

\begin{tabular}{|l|l|}
\hline $\begin{array}{c}\text { Organic (primary) intellectual } \\
\text { resources }\end{array}$ & Acquired (secondary) intellectual resources \\
\hline - founders' knowledge and & -new knowledge \\
experience & - copyright \\
- market contacts & - ancillary rights \\
- talent and behavioral skills of & - inventions (patents)* \\
employees & - utility models \\
- brand names (logo, name)* & - industrial models \\
- trademark & - brand names* \\
- website & - geographical indications \\
- patents* & - rights to new plant varieties \\
- corporate culture & - mask works \\
& - databases \\
& - non-disclosed information (trade secrets, \\
& know-how, recipes, processes, technologies, \\
& organizational techniques, etc., trade secrets) \\
& - license agreements \\
& -cooperation networks \\
\hline
\end{tabular}

* Patents and brand names in the company are dual. Depending on the business development stage, they are either organic (primary) resource or acquired (secondary) resource.

Source: Dereń A.M., Skonieczny J., Strategies for protecting intellectual resources in a company, Problemy Eksploatacji - Maintenance Problems, 2/2016 9101), s. 22.

17 Kościelniak H., Organizational and Financial Aspects of Functioning of Polish Companies, The Publishing Office of Czestochowa University of Technology, Czestochowa 2008.

18 Dollinger M. J., Entrepreneurship. Strategies and Resources, Marsh Publications, Lombard 2008, p. 32 -62.

19 Dereń A. M., Skonieczny J., Strategies for protecting intellectual resources in a company, Problemy Eksploatacji - Maintenace Problems, 2/2016 (101), p. 21-22. 
Organic (primary) intellectual resources are the founders' knowledge and experience, market contacts, the talent and behavioral skills of employees, brand names (logo, name), trademark, website, patents, and corporate culture.

The listed resources are primary and basic assets, which enable the creation of the company and commencement of business activities. These are resources that may be used in many places at the same time. They are not depreciated during use, but they usually are enriched and strengthened in the process of organizational development. The discussed resources are a unique foundation to organize and coordinate any processes in the company, in accordance with the vision or mission adopted by the founders.

On the contrary, acquired (secondary) intellectual resources are resources that are created as a result of the company's activities in the process of the conversion of primary resources into specific outcomes, assuming the form of, e.g., works (copyright), art performances (ancillary rights), inventions (patents), utility models, industrial models, brand names, geographical indications, new plant varieties, mask works, databases, and nondisclosed information (trade secrets, know-how, recipes, processes, technologies, organizational techniques, etc.).

These forms, as intangible products of the human mind, are components of intellectual resources, being decisive for the company's potential and its competitive position on the market.

It should be emphasized that inventions and brand names hold a particular position in intellectual resources. Resources may occur both at the stage of organizing the company and in the course of its activities. An invention patent may be a direct decisive factor for starting business activity or it may be a result of these activities. Therefore, innovativeness can be regarded as an intellectual resource with a dual character, i.e. as an organic or acquired resource.

In the authors' opinion, the presented classification of intellectual resources in a company has practical importance, since it makes it possible to conduct a comprehensive identification and analysis of resources held by the company. This, in turn, enables their protection and development based on a properly selected marketing strategy.

H.I. Ansoff distinguishes four generic marketing strategies. These $\operatorname{are}^{20}$ : market penetration strategy; market development strategy; product development strategy; diversification strategy. Until recently, a common and dominant strategy was the market penetration strategy (occupying and expulsing from the market), because - as compared to other marketing strategies, with a given unit of resources (e.g. 100\%) - its probability of success amounts to $50 \%$. The essence of the concerned strategy consists in the fact that the company, aiming at reduction in costs of manufacturing of an innovative product, offers the lowest price for this product on the market. By achieving that, the company becomes a price monopolist. This marketing strategy is effective until the emergence of a new product with a lower market price. In such a case, the three remaining strategies, i.e. market development, product development and diversification strategy, provide a sort of alternative. The first strategy is based on internationalization or segmentation of the market. According to the research, the probability of its success is $33 \%$, and the demand for resources is four times higher as compared to the market penetration strategy. On the other hand, the product development strategy (innovation and differentiation of product) requires eight times as many resources, with simultaneous reduction in the likelihood of success to $20 \%$. On the other hand, the diversification strategy (vertical, horizontal and lateral) requires from 12 to 16 times

20 Weis H. Ch., Marketing, Ludwigshafen (Rhein), Kiehl, 1990, 47, 48. 
as many resources as the penetration strategy, and the probability of success is the lowest, amounting only to $5 \%$.

The effectiveness of all the aforementioned marketing strategies and the reduction in the quantity of resources for their implementation should be the key aim in measuring the company operations. In our opinion, it is possible with the inclusion of legal protection of intellectual resources that constitute the basis for creating and implementing innovative products. example $^{21}$ :

Different IP rights may contribute to marketing strategy in different ways. For

- trade and service marks - a well-crafted mark is often a decisive tool for the success of enterprises in the market place. It will enable consumers to distinguish products or services from those of competitors and to associate products or services with desired qualities. Furthermore, it may play an important part in the ability of product or service to penetrate a new market, especially if care was taken while selecting or creating the mark so that it appeals to the target market;

- collective marks - the use of a collective mark (by a cooperative or an association of enterprises) allows different enterprises to benefit from a reputation acquired on the basis of the common origin or other common characteristics of the goods produced or services rendered by different enterprises. This is, particularly, the case where the origin or other common characteristics are the main contributing factor in determining the quality or good taste of a product or service;

- industrial designs - in today's highly competitive global economy, a visually attractive design alone may enable you to captivate a demanding and extremely diversified clientele. Through creative designs, enterprises could reach out and appeal to diverse groups of customers from different age groups, regions, cultures, etc. Having design rights on an attractive shape or style of a product may give you the much-needed edge over the competition;

- geographical indications - inherent in certain products from a particular region are characteristics that are due to the soil, climate or particular expertise of the people of that area which consumers of those products expect and have confidence in. Capitalizing on that reputation for products that emanate from such area or benefit from such skills in different marketing strategies make sound business sense in differentiating products from those of others. It is important to note that in the case of such products, the company must maintain the standards and quality expected of goods produced in that region or with such expertise;

patents - the market for innovative product can effectively be protected by obtaining patent protection. Being a patent holder can also open other business avenues such as licensing or strategic alliances;

- utility models - effective utilization of utility models, where such protection is available, can help enterprises stay abreast of their competitors. If strategically used, the protection of utility models can be an effective tool in positioning different enterprises in the marketplace, especially if enterprises are active in a business where technological advantage plays an important role in determining who holds a larger share of the market.

21 Why is Intellectual Property Crucial for Marketing the Products or Services of Your SME? http://www.wipo.int/sme/en/ip_business/marketing/marketing.htm (retrieved on: 3.04.2018). 
The intellectual resource protection instruments described above naturally shape the marketing strategies adopted by companies. Therefore, these instruments should be considered in the marketing-mix concept.

The marketing-mix concept is the basis for the marketing strategy. The name itself indicates that it consists of different elements of the marketing program, the correct application of which guarantees the marketing success of companies. The author of the marketing-mix concept is considered to be N.H. Borden ${ }^{22}$. Up to this day, its classification that is the most popular and commonly accepted by both theoreticians and practitioners is the $4 \mathrm{P}$ concept suggested 5 years later, in 1969, by E. J. McCarthy, covering the following instruments: product; price; promotion; place. This model perspective was obtained as a result of simplifying the list proposed by N.H. Borden (by incorporating in the «product» such elements distinguished by Borden as packaging and creation of the brand, to «promotion» of acquisition, advertising, sales promotion, demonstration of goods in shop windows, and resignation from such instruments as market research, warehousing and transport of goods). Gradual expansion of the marketing concept (mainly to cover services) and growth in competition forced the search for new factors distinguishing the company's marketing offer. Subsequent modifications proposed by Ph. Kotler, B.H. Booms, M.R. Bitner, and A. Payne ${ }^{23}$ concerned subsequent Ps: People; Process; Physical evidence.

The concept of marketing-mix cannot be considered a closed one. Our proposal to enrich this concept by further Ps (Patent and other Intellectual Property Rights) is an example of this. It fits in the contemporary trends typical of knowledge-based and creative economy, where intellectual resources constitute the groundwork for preparing and implementing the marketing strategy. The following table (Table 2) presents changes in the marketing-mix concept, taking account of our proposal.

Table 2 - Marketing-mix concept

\begin{tabular}{|l|l|l|l|}
\hline $\begin{array}{l}\text { Marketing-mix 4P } \\
\text { (E.J. McCarty) }\end{array}$ & $\begin{array}{l}\text { Marketing-mix 5P } \\
\text { (Ph. Kotler) }\end{array}$ & $\begin{array}{l}\text { Marketing-mix 7P } \\
\text { (B.H. Booms, M.R. } \\
\text { Bitner and A. Payne) }\end{array}$ & $\begin{array}{l}\text { Marketing-mix 8P } \\
\text { (Dereń, Skonieczny) }\end{array}$ \\
\hline- Product & - Product & - Product & - Product \\
- Place & - Price & - Price & - Patent (and other \\
- Promotion & - Place & - Place & Intellectual Property \\
& - Promotion & - Promotion & Rights) \\
& - People & - People & - Price \\
& & - Process & - Place \\
& & & - Promotion \\
& & & - People \\
& & & - Process \\
& & & \\
& &
\end{tabular}

Source: prepared by the authors.

Selection of the patent and other forms of legal intellectual property protection as instruments of the marketing-mix concept is closely related to the nature of an innovative

22 Borden N. H., The Concept of the Marketing Mix,

http://citeseerx.ist.psu.edu/viewdoc/download?doi=10.1.1.588.6640\&rep=rep1\&type=pdf, (retrieved on: 3.04.2018).

23 Pluta-Olearnik M., Services Marketing, Państwowe Wydawnictwo Ekonomiczne, Warsaw 1993, p. 37 - 42 ; Payne A., Essential of Services Marketing, Polskie Wydawnictwo Ekonomiczne, Warsaw 1997, p. 157 - 225. 
product, and through this connection affects the remaining elements, such as: price, place, promotion, personnel, process, and proof.

In the contemporary economy, the relationship between marketing and new technologies, constituting a result of the creative (intellectual) effort, is stressed more and more strongly. The integration of creative work, research and development work as well as production with the proper marketing strategy is the basis for effective implementation of the innovative process and affects its dynamics.

In the traditional perspective, it is assumed that marketing consists in searching for optimum sales channels, determining the right pricing strategy and promoting innovations created in the company. In the new perspective, marketing should cover the phase of creation and development of the innovative idea. The idea creation phase requires market analysis in terms of the needs of its participants. On the other hand, in the idea development phase, marketing is focused on seeking funds, investors interested in participating in the product development, as well as testing the new product concept.

The new concept suggested by the authors, containing $8 \mathrm{P}$, enables the expansion of marketing activities by the two aforementioned phases. Furthermore, it stresses the legal intellectual property protection as a kind of determinant for the development of the company's marketing strategy and its implementation. Therefore, the marketing strategy is not only one of the many functional strategies of the company, but the strategy of the company's business unit.

Conclusions from this research and prospects for further developments in this area. The new marketing-mix concept (Product, Patent and other Intellectual Property Rights; Price; Promotion; People; Process; Physical evidence) developed by the authors has important practical implications for innovative enterprises, especially those that base their market activity on new knowledge and information technologies. This developed concept is an integral part of marketing strategies such as: market penetration, product development, market development, diversification, with strategies for protection of intellectual property resources (patent, sale, license, franchise).

1. Ansoff, H.I. (1985). Strategic Managament. Państwowe Wydawnictwo Ekonomiczne Warsaw.

2. Borden, N. H. The Concept of the Marketing Mix. citeseerx.ist.psu.edu Retrieved from http://citeseerx.ist.psu.edu/ viewdoc/download?doi=10.1.1.588.6640\&rep=rep1\&type=pdf.

3. Conrady, R., Jaspersen, T., \& Pepel,s W. (Hrsg.). (2002). Online Marketing Instrumente. Luchterhand Verlag.

4. Dereń, A., \& Skonieczny, J. (2016). Organizational management. Process approach. Difin Publishing House.

5. Dereń, A. M., \& Skonieczny, J. (2016). Strategies for protecting intellectual resources in a company. Problemy Eksploatacji-Maintenace Problems, 2/2016 9101, 21-22.

6. Dollinger, M. J., (2008). Enterpreneurship. Strategies and Resources. Marsh Publications, Lombard.

7. Evans, L. (2011). Social Media Marketing. Discover the potential of Facebook, Twitter and other social networking sites, Helion.

8. Fonfara, K. (1999). Affiliate Marketing, Warsaw: Polskie Wydawnictwo Ekonomiczne.

9. Grant, R. M. (2011). Contemporary analysis of strategies. Warsaw: Wolters Kluwer business Publishing House.

10. Kościelniak, H. (2008). Organizational and Financial Aspects of Functioning of Polish Companies. Czestochowa: The Publishing Office of Czestochowa University of Technology.

11. Królewski, J., \& Sala, P. (2016). E-marketing. Contemporary trends. Starter pack. Warsaw:Wydawnictwo Naukowe PWN.

12. Levinson, J. C. (1998). Guerrilla Marketing. Warsaw: Polskie Wydawnictwo Ekonomiczne. 
13. Levinson, J. C., \& Rubin, Ch. (1998) Guerrilla Marketing, on-line. Warsaw: Polskie Wydawnictwo Ekonomiczne.

14. Mazzucato, M. (2016). Enterprising state. Poznań: Wydawnictwo Ekonomiczne Heterodox.

15. Payne, A. (1997). Marketing services. Warsaw: Polskie Wydawnictwo Ekonomiczne.

16. Pluta-Olearnik, M. (1993). Marketing services. Warsaw: Państwowe Wydawnictwo Ekonomiczne.

17. Rifkin, J. (2014). Society of zero endpoints. Studio Emka Publishing House.

18. Silk, A. (2008). What is marketing? Dom Wydawniczy Rebis, Poznań.

19. Weis, H. Ch. (1977). Marketing. Friedrich Kiehl verlag, Ludwigshafen (Rhein).

19; Hofner, K. (1977). Probleme bei den Verwierklichung des Marketingkonzept im Ivestitionsguterbereich. «Rationalisierung», 10.

20. Weis, H. Ch. (1990). Marketing. Ludwigshafen (Rhein), Kiehl.

21. Why is Intellectual Property Crucial for Marketing the Products or Services of Your SME? www.wipo.int. Retrieved from http://www.wipo.int/sme/en/ip_business/marketing/marketing.htm.

21. «Shared responsibility. The role of marketing», joint publication edited by N. Ćwik. odpowiedzialnybiznes.pl Retrieved from http://odpowiedzialnybiznes.pl/wp-content/uploads/2012/04/ Wsp\%C3\%B3lna-odpowiedzialno\%C5\%9B\%C4\%87.-Rola-marketingu-13.pdf.

Дерейн А.-М., кандидат технічних наук, факультет комп'ютерних наук та менеджменту, Врочлавський університет науки і техніки (Вроцлав, Польща)

Сконечний Я., кандидат економічних наук, факультет комп'ютерних наук та менеджменту, Вроилавський університет науки і техніки (Вроилав, Польща)

\section{Маркетинг інтелектуальної власності}

Маркетинг визначається різним чином. Проте, найчастіше сприймається як процес, описаний в маркетинг-мікс 4P, маркетинг-мікс 5р і маркетинг-мікс $7 P$ у створенні иінності для спожсивачів. Нова конщепція маркетинг-мікс, яка розроблена авторами (продукт, патент $i$ інші права інтелектуальної власності; иіна; Promotion, люди, процес, речові докази), має важливе практичне значення для інновачійних підприємств, особливо для тих, які засновують свою ринкову діяльність на нових інформаційних технологіях. Розроблена модель є невід'ємною частиною рейкової моделі, яка розроблена авторами, $i$ яка поєднує в собі маркетингову стратегію (проникнення ринку, розробка продукиії, розвиток ринку, диверсифікація) зі стратегіями захисту ресурсів інтелектуальної власності (патент, продаж, лічензія, франшиза).

Ключові слова: маркетинг, концепція маркетингу, інтелектуальна власність, патент.

Received to the editor April 9, 2018 